\title{
Saint Eugenia Outside-Inside-Outside Rome: An Iconographic Continuity?
}

\author{
Andrea-Bianka Znorovszky \\ Austrian Academy of Sciences, Vienna; \\ Universität Salzburg, Institut für Realienkunde des \\ Mittelalters und der Frühe Neuzeit
}

\section{Abstract}

This essay deals with the iconography of Saint Eugenia demonstrating both the continuity and the development of her visual characteristics as a martyr, with special emphasis on the area of Rome, Italy. Her cult contributed to the promotion and multiplication of her imagery in Rome and northern Italy. Thus, Eugenia's iconography from Ravenna becomes a starting point for the reconstruction of her early sixthseventh-century depictions in Rome. This research concludes that although this holy woman belongs to the group of cross-dressed saints, Saint Eugenia is (visually and textually) constructed as a woman due to her positioning into groups of female saints.

Keywords: Saint Eugenia of Rome; cross-dressing; iconography; martyrdom; frescoes; relics. 


\title{
Saint Eugenia Outside-Inside-Outside Rome: An Iconographic Continuity? ${ }^{1}$
}

\author{
Andrea-Bianka Znorovszky \\ Austrian Academy of Sciences, Vienna; \\ Universität Salzburg, Institut für Realienkunde des \\ Mittelalters und der Frühe Neuzeit
}

Saint Eugenia of Rome, the daughter in a Roman pagan family, hears the preaching of Christians and decides to leave her home. In order to enter a monastic community, whose abbot is not fond of women, she cross-dresses. Later, she becomes the abbot of that very monastery and is accused by a woman, Melanthia, of indecent behaviour. Proving her innocence, she undresses in public and then converts her family to Christianity. Her father, Phillipus, becomes a bishop and dies a martyr's death. Eugenia eventually returns to Rome where she establishes a female religious community, and later is tortured and dies as a martyr in Christ. ${ }^{2}$

The motif of the saint in disguise was introduced in the hagiographic genre around the fourth century and reached its peak in the East sometime between the sixth and the eighth century, ${ }^{3}$ while in

\footnotetext{
${ }^{1}$ This essay is based on the fifth chapter of my doctoral dissertation, titled "Close to the Mother of God: The Innocence and Martyrdom of Saint Eugenia of Rome": Andrea-Bianka Znorovszky Between Mary and Christ: Depicting Cross-Dressed Saints in the Middle Ages (c. 1200-1600) (Budapest: Central European University, doctoral dissertation, 2016).

2 Saint Eugenia of Rome was martyrized in the third century A.D. More on her vita, see AASS Sept. 3: 761-762; She is venerated on December 24th $25^{\text {th }}$.

3 Sylvia Schein, "The Female Men of God and Men Who Were Women. Female Saints and Holy Land Pilgrimage During the Byzantine Period," Hagiographica 5 (1998): 17. On the transfer of this motif from East to West see, Enrico Morini, "Santità monastica femminile in abiti maschili nell'Oriente cristiano," in Giustina e le altre. Sante e culti
} 
the West it was included in hagiographic collections, such as the Legenda Aurea. These lives, in a nutshell, concentrate on stories of women who wore men's clothes, fled the world to follow Christ, and joined in monasteries or, sometimes, retired in solitary places. Eugenia of Rome belongs to a particular group of cross-dressed saints, the monachoparthenoi, virgin monks, alongside Euphrosyne of Alexandria, Margareta Pelagius, and Marina the Monk.

This essay concentrates on the development of Saint Eugenia's imagery in relation to her cult in Italy. It demonstrates that although scholarship classifies her as a cross-dressed saint, the continuity in her representations as martyr emphasized her womanhood and not her disruptiveness. In this sense, this study connects early fifth-seventhcentury mosaics and cult of relics to later fifteenth-century representations of Eugenia in order to reconstruct her iconography in northern Italy.

Research on cross-dressed saints' lives is fairly rich. It has been a popular research topic especially starting from the 1970s. Literary, psychological, socio-religious, theological, and textual interpretations have attempted to explain the phenomenon using different approaches.

Among the earliest interpretations are those of Herman Usener, ${ }^{4}$ in the nineteenth century, and of Hippolyte Delehaye ${ }^{5}$ at the beginning of the twentieth century. Usener considered that the transvestite motif has a pagan origin which was passed into Christian hagiography through Greek romances. Furthermore, he pointed out that the saint's disguise is a survival of the cult of the bisexual Aphrodite of Cyprus. Recent interpretations belong to John Anson, ${ }^{6}$ Évelyne Patlagean, ${ }^{7}$ Vern L. Bullough, ${ }^{8}$ Sylvia Schein, ${ }^{9}$ Stephen J. Davis, ${ }^{10}$ and others. ${ }^{11}$ Anson

femminili in Italia settentrionale dalla prima età cristiana al secolo XII, ed. Andrea Tilatti, Francesco G.B. Trolese (Padova: Viella, 2009), 271-300.

${ }^{4}$ Hermann Usener, Legenden der heiligen Pelagia (Bonn: Adolph Marcus, 1879), I-XXIV.

${ }^{5}$ Hippolyte Delehaye, The Legends of the Saints (Brussels, 1905, 1906, reprinted Dublin: Four Courts Press, 1998), 51 and 150-60.

6 John Anson, "The Female Transvestite in Early Monasticism," 1-32.

7 Évelyne Patlagean, "L’histoire de la femme déguisée en moine," 597-623.

8 Vern L. Bullough, "Transvestites in the Middle Ages," The American Journal of Sociology 79, No. 6 (1974): 1381-94; and also Vern L. Bullough and James Brundage, Handbook of Medieval Sexuality: A Book of Essays (New York: Garland Publishing, 1996), 223-242; and Vern Bullough, Cross Dressing, Sex and Gender, 51-57.

9 Sylvia Schein, "The Female Men of God," 1-36. 
considers that these vitae were written by "monks for monks" and that they do not record real female behaviour. Patlagean points out that the origin of the transvestite phenomenon is connected to Christian practice thought Late Antiquity, while Delcourt ${ }^{12}$ explains it from a psychological point of view. For Delcourt, transvestitism signifies a break from a preceding existence, connected with hostility towards the saint's family. Bullough's conclusion is that women transvestite saints gained social status as compared to male cross-dressers, who lost status by transvestitism. Stephen J. Davis' study analyses the phenomenon from an intertextual perspective ${ }^{13}$ by identifying the origin of the motif not only in the vitae of Thecla and Pelagia, as did other scholars, but in various patterns mostly drawn from the Bible or hagiography. Natalie Zemon Davis ${ }^{14}$ argues that the image of the disordered woman did not have the sole function of keeping women in their place, but was also employed to sanction political disobedience or widen their behavioural options. From this point of view, she argues that cross-dressed saints function as proof that women can do more than is expected of them: ruling the lower in themselves and deserving to be like men. Last but not least, Crystal Lubinsky ${ }^{15}$ proves that these saints remain women to the end and are praised as holy women even when they use masculine disguise.

10 Stephen J. Davis, "Crossed Texts, Crossed Sex: Intertextuality and Gender in Early Christian Legends of Holy Women Disguised as Men," Journal of Early Christian Studies 10, No. 1 (2002): 1-36.

11 See Susan Ashbrook Harvey, "Women in Early Byzantine Hagiography: Reversing the Story," in That Gentle Strength: Historical Perspectives on Women in Christianity, ed. L. Coon, Katherine J. Haldane, and Elisabeth W. Sommer (Charlottesville: University Press of Virginia, 1990), 36-59; and also an analysis on Perpetua by Elizabeth Castelli, "I Will Make Mary Male: Pieties of the Body and Gender Transformation of Christian Women in Late Antiquity," in Body Guards: the Cultural Politics of Gender Ambiguity, ed. Julia Epstein and Kristina Straub (New York: Routledge, 1991), 29-49.

12 Marie Delcourt, "Le Complexe de Diane et l'hagiographie Chretienne," Revue de l'histoire des religions 153 (1958): 1-33.

13 Stephen J. Davis, "Crossed Texts, Crossed Sex," 1-36. He identifies the origin of the motif not only in the vitae of Thecla and Pelagia, as did other scholars, but in various patterns mostly drawn from the Bible or hagiography.

${ }_{14}$ Natalie Zemon Davis, "Women on Top," in Society and Culture in Early Modern France (Stanford: Stanford University Press, 1975), 131-132.

15 Crystal Lubinsky, Removing Masculine Layers to Reveal a Holy Womanhood. The Female Transvestite Monks of Late Antique Eastern Christianity (Turnhout: Brepols, 2013). 
This essay analyses the visual representations of one of these crossdressed saints, namely Saint Eugenia of Rome, as this aspect has not yet been thoroughly addressed. As part of the monachoparbtenoi group, she shares the feature of refusing marriage/running away and hiding in a monastery, as reflected in both textual and visual narratives. In fact, the visual representations are those which offer an elaborated iconography (religious syncretism, masculine representations, etc.) in contrast to textual sources which do not possess any important additions or omissions.

\section{Eugenia outside Rome: an early phase}

Following her martyrdom, Eugenia's body was taken to a religious establishment. ${ }^{16}$ The information offered by her vita is an important starting point in establishing the initial topos of her veneration, as it indicates not only the existence of a basilica, but also the place where her relics were deposited. The actual existence of such a place of worship underlines the promotion of her cult and the possibility that Eugenia was more than just a fictitious character. Although the basilica dedicated to her does not exist anymore, various historical sources help identify and re-construct both her cult and iconography which spread as her importance grew.

One of the above-mentioned historical evidence is connected to topography. Namely, Eugenia's basilica was supposedly situated on the Via Latina, in the cemetery of Appronianus, which was later on, in the sixth-seventh centuries, known as the cemetery of Saint Eugenia ${ }^{17}$ because of the growth of her fame. This indicates a process of reconfiguration determined by the existence of relics deposited within the walls of a holy place. That Eugenia's story is not only a hagiographical fact is further indicated by the inclusion of her church among the lists of renovated buildings by several popes. In the eighth

\footnotetext{
16 Auctore incerto, "Vita Sanctae Eugeniae, virginis ac martyris," in AASS, Sept. 3: 761 62.

17 Agostino Amore, I martiri di Roma (Todi: Tau Editrice, 2013), 132-133. On the possibility that the cemetery of Appronianus was not a cemetery for Christians, but for gentiles, see Domenico Bartolini, Cimitero d'Aproniano ditto anche di Santa Eugenia su la via Latina (Rome: Tipografia delle delle Arti, 1840), 12.
} 
century, Pope John VII ordered the restoration of the church, ${ }^{18}$ while Pope Adrian I, still in the same century, not only restored the basilica, ${ }^{19}$ but also built a nunnery next to it; finally, Pope Leo III is attested as offering donations to the church in the ninth century. ${ }^{20}$ These references are among the few that mention the existence of a church dedicated to Saint Eugenia on the Via Latina. The above mentioned detail of the nunnery, again, exemplifies the importance of Eugenia's cult, the development, and the reconstruction of a previous place of veneration which implies the increase of its space. Furthermore, the existence of this nunnery, next or close to Eugenia's basilica, seems to re-construct an episode of her life, namely, that of the saint establishing a nunnery in Rome, only that this time Eugenia is close to her followers through her relics.

E. Josi, in his Cimitero Cristiano sulla Via Latina, ${ }^{21}$ states that there is no liturgical reference in the depositio martyrum or in Pope Damasus' poetry about the martyrs of the Via Latina, including Eugenia, and that she turns up celebrated on the $25^{\text {th }}$ of December in religious texts such as Jerome's Martyrology or the Sacramentary of Leo I. ${ }^{22}$ Nevertheless, the above-mentioned topographical details strongly suggest the existence of her cult.

Other historical sources, such as itineraries, indicate the existence of Eugenia's basilica. In his study, La Roma sotterranea, ${ }^{23}$ de Rossi includes

18 Louis Duchesne, Le Liber Pontificalis, texte, introduction et commentaire, vol. I (Paris: Ernest Thorin, 1886), 385. Duchesne also mentions the inclusion of the church in seventh-century itineraries, see 386 , note 3 .

19 Duchesne, Le Liber Pontificalis, vol. I, 509.

20 Duchesne, Le Liber Pontificalis, vol.I, 510 and Duchesne, Le Liber Pontificalis, vol. II, (1886), 25.

${ }^{21}$ Enrico Josi, "Cimitero Cristiano sulla Via Latina," Rivista di archeologia cristiana 16 (1939): 22. Josi states that there must have been a church dedicated to her in the sixth century.

22 Amore, I martiri di Roma, 132, note 39. The Martyrologium Cambrense mentions the passion of Saint Eugenia on the $25^{\text {th }}$ of December (p. 381). The Martyrologum Romanum (Rome: Typis Polyglottis Vaticani, 1930), 315, mentions Eugenia among the martyrs of the cemetery of Apronianus on the $25^{\text {th }}$ of December. On Eugenia in various martyrologies and other religious texts, see: Zéphyrin Toursel, Histoire de Sainte Eugénie, vierge romaine, et de sa famille (Lille: Jesuit Library of Lille, 1860), 56-59.

23 Giovanni Battista de Rossi, La Roma sotterranea Cristiana, Tomo I (Rome: CromoLitografia Pontificia, 1864). See also Hippolyte Delehaye, Étude sur le légendier romain, les saints de novembre et de décembre (Brussels: Bollandistes, 1936): 171-172. See also, Jacques 
information from the Itinerarium ex unico codice Salisburgensi; Epitome Libri de Locis Sanctorum Martyrum e codicibus Salisburgensi puro, Wirceburgensi puro et Salisburgensi interpolato; Notitia portarum, viarum, ecclesiarum circa urbem Romam e Willelmo Malmesburiensi, and from Topographia Einsiedlenis; all the references indicate the existence of a construction built tin her honour:

On the Via Latina outside the city, on the left [is] the oratory of Saint Mary and [the oratory of] Saint Gordianus, on the right [is] the oratory of Saint Januarius, Saint Sixtus, Saint Eugenia, and Saint Theodorus. ${ }^{24}$

Looking at the dating of these itineraries and the notes on the churches of Rome, it is clear that a construction dedicated to Saint Eugenia still existed outside of Rome between the eighth-ninth centuries and the twelfth century, ${ }^{25}$ One of the earliest itineraries is the one in the Einsiedeln manuscript dating from the eighth-ninth century. ${ }^{26}$ The De locis sanctis martyrum quae sunt foris civitatis Romae, composed around the ninth-tenth century still mentions her church, ${ }^{27}$ while the Gesta regum Anglorum of William of Malmesbury in the twelfth century states the same. This underlines that the church dedicated to Saint Eugenia still existed as late as the twelfth century.

Finally, the growth of Eugenia's importance is reflected in poems of Avitus, bishop of Vienne, and Venantius Fortunatus. ${ }^{28}$ All of the above

Dubois, Le Martyrologe d'Usuard. Texte et commentaire (Brussels: Société des Bollandistes, 1965), 302, for the $13^{\text {th }}$ of September. See also the same martyrology of Usuard, 148.

24 "Topographia Einsiedlensis," in de Rossi, La Roma sotterranea Cristiana, I, 180-181. Other references on the basilica dedicated to Saint Eugenia: Itinerarium ex unico codice Salisburgensi in de Rossi, La Roma sotterranea Cristiana, I, 180-181. Also Epitome Libri de Locis Sanctorum Martyrum e codicibus salisburgensi puro,Wirceburgensi puro et Salisburgensi interpolato in de Rossi, La Roma sotterranea Cristiana, I, 180-181. Also Notitia portarum, viarum, ecclesiarum circa urbem Romam e Willelmo Malmesburiensi in de Rossi, La Roma sotterranea Cristiana, I, 180-181. De Rossi's work offers indications concerning the burial places of the two eunuch martyrs who followed Saint Eugenia.

25 Valentini Zucchetti, Codice topografico della città di Roma, vol. II (Rome: Tipografia del Senato, 1942), 102, 134.

26 See Zucchetti, Codice topografico, 102, 199 (see also p. 157 for dating).

27 See note 5 , in De locis sanctis martyrum quae sunt foris civitatis Romae in Zucchetti, Codice topografico, 112.

${ }^{28}$ Josi, "Cimitero Cristiano," 23-24. On the possible date of the composition of Eugenia's legend, see Albert Dufourcq, Étude sur le Gesta Martyrum Romains (Paris: Albert Fontemoing éditeur, 1900), 299-300. As Eugenia is appreciated by Avitus, who died in 526 , this suggests that her legend is prior to the sixth century, while a certain bishop 
mentioned topographical, historical, and literary sources indicate the existence of a certain establishment dedicated to a saint named Eugenia outside of Rome. Unfortunately, none of these sources offer any information on the depictions of Saint Eugenia. This leaves us with the only possibility of imagining and hypothesizing how her iconography might have looked like.

\section{An iconographic re-construction}

The iconography can be tentatively reconstructed on the basis of early surviving images in other regions of Italy. The possible patterns of representation may offer a glimpse on how she might have been depicted in a church which was not only dedicated to her, but which also hosted her relics.

The earliest surviving representations of Eugenia can be seen in Ravenna in three fifth-sixth-century constructions: Sant'Apollinare Nuovo, and the Capella Arcivescovile. ${ }^{29}$ Inside the Sant'Apollinare Basilica, there are fifth- and early-sixth-century mosaic representations of martyrs and virgins..$^{30}$ Eugenia is depicted on the left wall of the nave in the company of Saints Sabina and Cristina. As a beautiful nimbed, veiled, young woman, Eugenia holds a crown in her hands. The only iconographic detail which differentiates her from the other virgin martyrs is the inscription of her name: $\left\langle S_{c a}\right.$ Evgenia $>$. Eugenia is depicted in a procession (Fig. 1) which gathers the virgin martyrs and the three Magi, approaching the Mother of God and the Son of God. The second representation from Ravenna is found in the Capella Arcivescovile, in the North West arch, where Eugenia is depicted bust length, frontal, as an icon similarly to an imago clipeata, once again veiled and having her name inscribed above her image. ${ }^{31}$ A similar

Helenus, who baptized Eugenia, is mentioned in Rufinus's Historia Monachorum, Rufinus dying in 410.

29 Maria Pia Fabbri, I mosaici di Ravenna (Forli: Carta Canta Editore, 2010), 49, 105. Amore, I martiri di Roma, 132-133. Josi, "Cimitero Cristiano," 24-25. See also Hippolyte Delehaye, Les Origines du culte des martyrs (Brussels: Société des Bollandistes, 1933), 326327.

30 Angelo Lorizzo, I mosaici di Ravenna (Ravenna: Longo Editore, 1976), 27.

31 Paolo Verzone, "Il palazzo arcivescovile e l'olatorio di S. Andrea," in Corsi di cultura sull'arte ravennate e bizantina, ed. Giuseppe Bovini (Ravenna: Edizioni Dante, 1966), 450452. 
representation to that from Sant'Apollinare Nuovo, also dating from the sixth-century, is found in Poreč, in the Eufrasian Basilica, on the central apse border (Fig. 2). ${ }^{32}$ The Catacomb of S. Gennaro ${ }^{33}$ from Naples also hosts a later ninth-tenth century representation of the saint, while an eleventh century depiction shows Eugenia holding a crown wrapped in a pallium. ${ }^{34}$

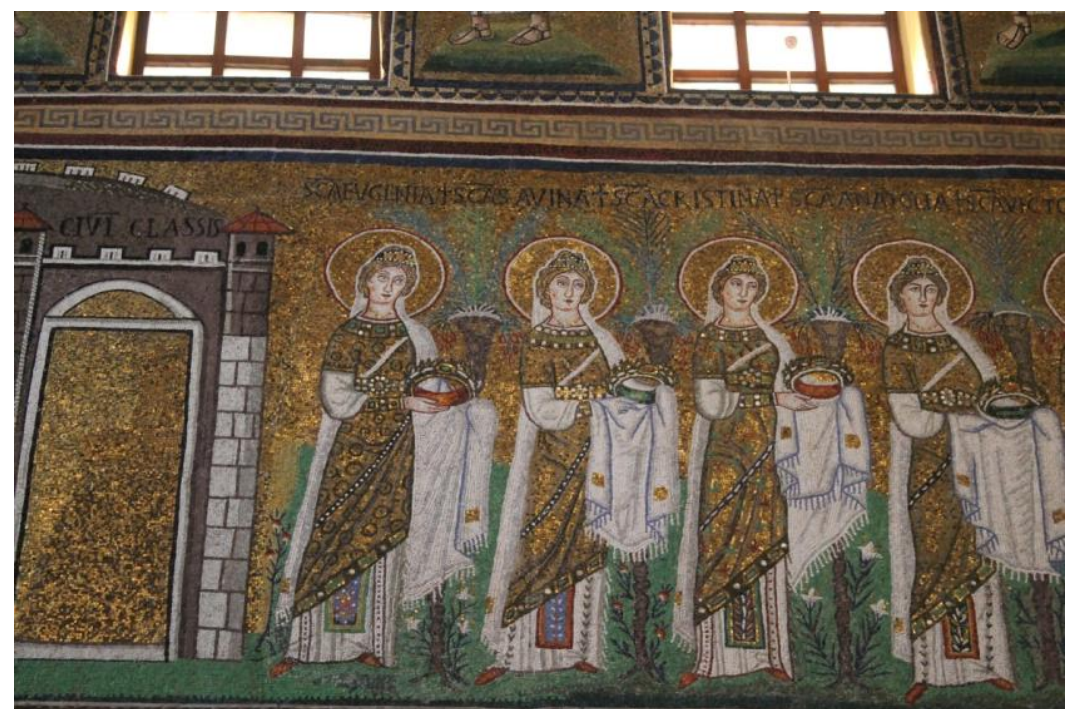

Fig. 1. Procession of female saints, fifth-sixth century. Ravenna, Italy, Saint Apollinare Nuovo (photo: the author)

The early representations of Saint Eugenia bear common elements as all concentrate on depicting a young virgin martyr either bust length or in a standing position. The prevalent iconographic attributes of

32 Ann Terry, Henry Maguire, Dynamic Splendor. The Wall Mosaics in the Cathedral of Eufrasius at Poreč, vol. I (Philadelphia: The Pennsylvania State University Press, 2007), 67, for more on the similarities between Sant'Apollinare Nuovo and the Cathedral of Eufrasius.

33 Josi, "Cimitero Cristiano," 25.

34 George Kaftal, Saints in Italian Art, Iconography of the Saints in Central and South Italian Schools of Painting (Florence: Sansoni, 1975), 408. 
Eugenia's early depictions, outside of Rome, are the rich virgin martyr dress $^{35}$ or the crown wrapped in a pallium.

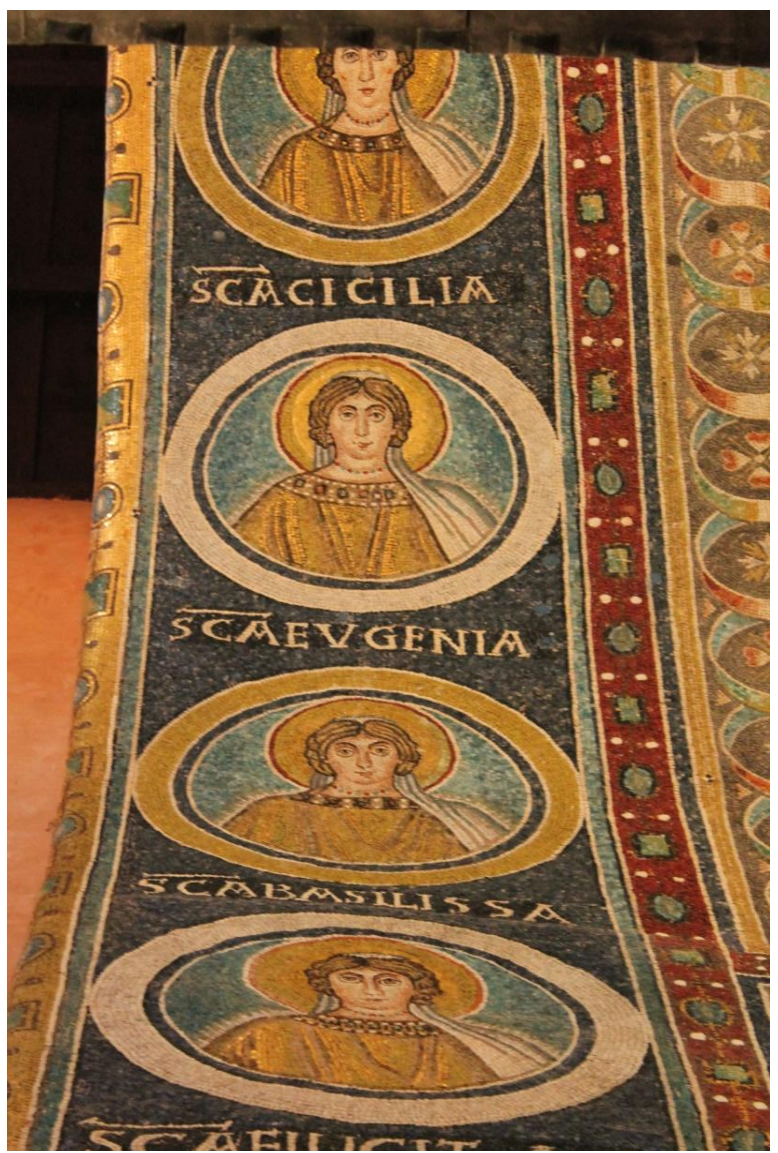

Fig. 2. Saint Eugenia, sixth century.

Poreč Cathedral, Croatia (photo: the author)

All these visual representations concentrate on Eugenia's womanhood in contrast to interpretations of martyrdom according to

35 George Kaftal, Saints in Italian Art, Iconography of the Saints in Tuscan Painting (Florence: Tipografia “L”Impronta," 1952), 350. George Kaftal, Saints in Italian Art, Iconography of the Saints in the Painting of North East Italy (Florence: Sansoni, 1978), 299-300. 
which female martyrs embody a certain type of virility that is directed against one's state or family. ${ }^{36}$ Eugenia is generally grouped with other female martyrs suggesting the mystical love topos, as the Saint Apollinare Nuovo imagery suggests. ${ }^{37}$

A basilica dedicated to a titular saint, must include at least one image of that particular saint. Looking at the depiction of Saint Agnes (Fig. 3) in Sant'Agnese Fuori le Mura, Rome, a seventh-century basilica, we will observe that Saint Agnes is depicted in the main apse flanked by Pope Honorius and Pope Symmachus. This implies that a similar image to those found in Ravenna, Naples or Poreč might have been depicted in Eugenia's basilica. Furthermore, her later imagery in the Church of the Apostles, Rome, testifies the survival and the development of the virgin martyr's pattern.

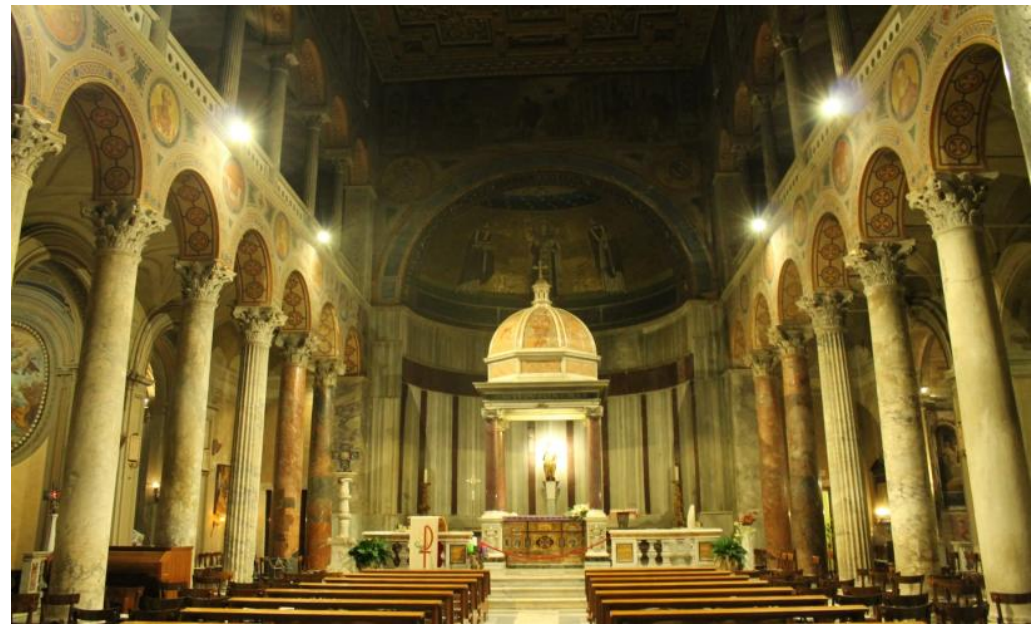

Fig. 3. Saint Agnes, seventh century.

Rome, Sant'Agnese fuori la mura church (photo: the author)

\footnotetext{
36 See for instance, Barbara Baert, "More Than an Image: Agnes of Rome: Virginity and Visual Memory," in More than Memory: the Discourse of Martyrdom and the Construction of Christian Identity in the History of Christianity, ed. Johan Leemans (Leuven: Peeters Publishers, 2005), 140-144. Jane Tibbetts Schulenburg, Forgetful of Their Sex: Female Sanctity and Society, c. 500-1100 (Chicago and London: The University of Chicago Press, 1998), 159.

37 George Duby, Power and Beauty: Images of Women in Art (London: Tauris Parke Books, 1992), 54.
} 


\section{Eugenia in Rome: a later phase}

Today, the Church of the Apostles in Rome is divided in one nave and two side aisles with six chapels. ${ }^{38}$ The former Chapel of Saint Eugenia, the third on the right side, is the second in importance. ${ }^{39}$ It was reconstructed and rededicated to Saint Anthony, in 1649, and offered to his confraternity. The tomb containing Eugenia's, Claudia's, and other martyrs' relics is still placed in its altar (Fig. 4). 40 Although dedicated to Saint Anthony, the chapel nevertheless initially housed two seventeenth-century statues, one of Eugenia (by Francesco Peroni) and another of Claudia (by Domenico Guidi), positioned near the altar. Today, they are placed in the crypt. ${ }^{41}$

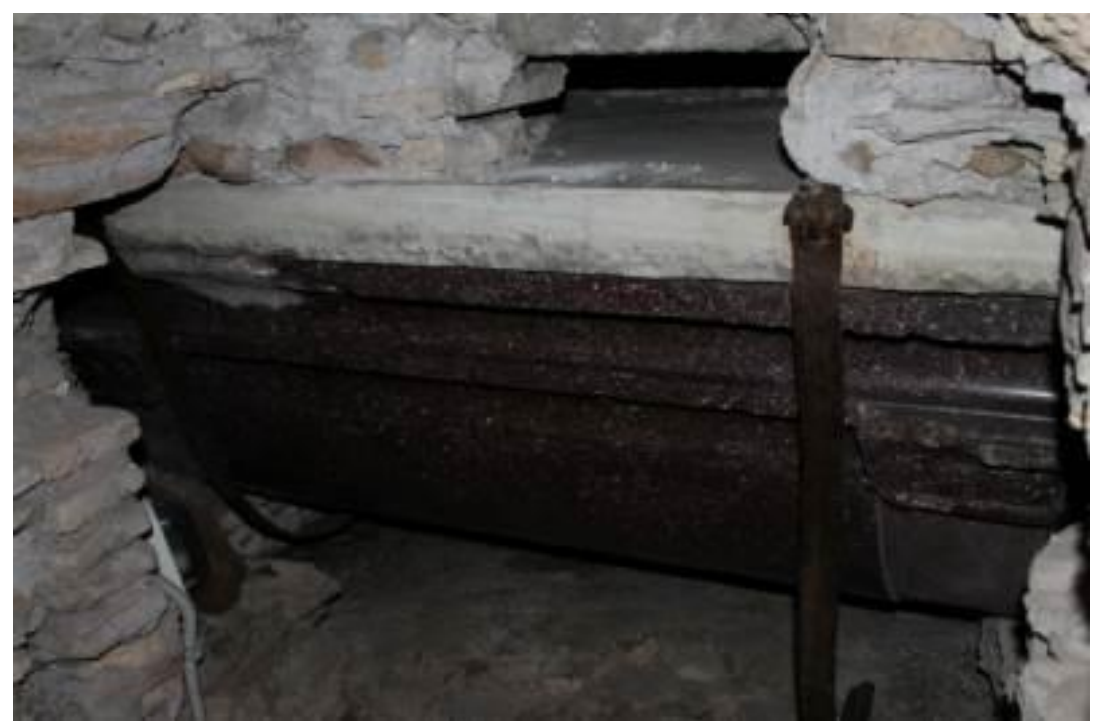

Fig. 4. Tomb of Saint Eugenia, Saint Claudia, and other martyrs. Church of the Apostles, Rome (photo: the author)

\footnotetext{
38 Isidoro Liberal Gatti, La Basilica dei Santi XII Apostoli (Rome: L' Apostoleion, 1988), 14.

${ }^{39}$ Emma Zocca, La Basilica dei Ss. Apostoli in Roma (Rome: F. Canella, 1959), 34, 116.

${ }^{40}$ Liberal Gatti, La Basilica dei Santi XII Apostoli, 22.

${ }^{41}$ Liberal Gatti, La Basilica dei Santi XII Apostoli, 33. See also Josi, "Cimitero Cristiano," 36.
} 
Scholarship offers multiple possibilities for the transfer of Saint Eugenia's relics inside the walls of Rome: some argue that the date of the transfer is unknown, ${ }^{42}$ while others state that it happened around the ninth century ${ }^{43}$ or even as late as the eighteenth century. ${ }^{44} \mathrm{I}$ consider the last hypothesis improbable as there is written evidence that Eugenia's relics had already been inside the Church of the Apostles by the fifteenth century. Furthermore, if Eugenia's relics had been in her Via Latina basilica in the eighteenth century, the construction would have survived perhaps until today or it would have at least been recorded in later documents.

I agree with the hypothesis which dates the transfer to somewhere around the eighth or ninth century. E. Josi ${ }^{45}$ mentions that in the eighth century there was a tendency of translating relics inside Rome, including Eugenia's relics. Accordingly, in the ninth century, Pope Stephen VI reconstructed the Basilica of the Apostles and replaced the bodies of Eugenia, Claudia, and twelve other martyrs in a porphyry sarcophagus. ${ }^{46}$ One can add a thirteenth-century (or fourteenthcentury) inscription which includes Eugenia's name, suggesting that her

42 Amore, I martiri di Roma, 133. Gian Domenico Gordini, "Eugenia, Filippo, Claudia, Sergio, Abdon, Proto e Giacinto," in Bibliotheca Sanctorum vol. I (Rome: Cità Nuova Editrice, 1964), 183.

${ }^{43}$ See, for instance, Domenico Bartolini, Cimitero d'Aproniano ditto anche di Santa Eugenia su la via Latina (Rome: Tipografia delle delle Arti, 1840), 9. Bartolini states that Eugenia's relics were transferred to Rome also because of perils.

${ }^{44}$ See Martinelli, Roma ex ethnica sacra, 65 reproduced in Josi, "Cimitero Cristiano," 36.

45 Josi, "Cimitero Cristiano," 37.

46 Lanciani, Storia degli Scavi di Roma, 3 reproduced in Josi, "Cimitero Cristiano," 36. Malvasia Bonaventura, Compendio bistorico della ven. Basilica di SS. Dodeci Apostoli di Roma, sua fondarione, origine, nobilita, sito, pretiosi tesori delle Sante Reliquie, che in quella si contengono (Rome, 1665), 193-194: "Sotto l'Altare di S. Eugenia, e S. Antonio di Padoa vi sono li Corpi delle Sante Eugenia Vergine, e Martire, e Claudia Martire madre di S. Eugenia." The author also mentions the existence of a reliquary that contains the relics of several martyrs: "Vn altro vaso d'Argento con dentro delle reliquie di S. Eugenia Vergine, e Martire, di S. Catherina, e de Ss. Crisanto, e Daria." 196. Ippolito Mazzucco, Iscrizioni della Basilica e convento dei Santi Dodici Apostoli in Roma (Rome: L'Apostoleion, 1987), 134. See also, Clemente Busiri-Vici, "Un ritrovamento eccezionale relative all'antica basilica dei Ss. Apostoli," in Roma, Fede e arte, 8 (1960): 70-83; on Stephen VI's translation of Eugenia's relics inside the Church of the Apostles after its reconstruction (due to flooding and earthquake), 72, 75. 
relics had already been transferred inside Rome. ${ }^{47}$ There is another detail which has to be added to this transfer process: French and Spanish sources mention that the relics' transfer on French and Spanish territories happened in the ninth century. ${ }^{48}$ Therefore, moving the relics from outside to inside the walls of the city could have happened around the ninth century if we have also consider the date of the reconstruction of the Church of the Apostles.

Built by Pope Pelagius I in the sixth century, the Church of the Apostles was placed at the cross-roads between natural barriers and the city, between the old and new parts of Rome. ${ }^{49}$ It is important to mention in the context of Eugenia's relics is that the church was not built on a martyrium, 50 therefore, the church, although initially dedicated to Saints Philip and Jacob, seems to have needed a martyr's relic in a certain period, the sixth century, when Saint Eugenia's cult was reaching its peak (as her representations from Ravenna and Poreč suggest). It must be highlighted that both outside and inside Rome, Eugenia's basilica was continually on the list of papal reconstructions and renewal; furthermore, it seems that it was a pope who had actually transferred her relics inside Rome. In addition, in the ninth century, the Church of the Apostles was reconstructed by Pope Stephen VI and possibly her (entire) relics were transferred inside Rome as suggested by Malvasia's records of relics. ${ }^{51}$ As for the former basilica which hosted her relics, it seems that it survived at least until the twelfth century as suggested by Malmsbury's itinerary which still bears the name of the titular saint.

47 Toursel, Histoire de Sainte Eugénie, 271. See also Mazzucco, Iscrizioni della Basilica, 133. On the tombstone in the vestibule of the basilica: "Dalla parte destra i corpi di Eugenia vergine e di altri Martiri."

48 There is information with regard to the possibility that Eugenia's relics (or at least parts of it) were transferred to Florence where she, again, was venerated as a martyr -as one of her antiphons mention in Casimiro Stolfi, Leggende di alcuni santi e beati venerati in Santa Maria degli Angeli di Firenze (Bologna: Commissione per testi di lingua, 1968), 17 and 18.

49 Alessandro Valenti, "Le origini," in Il Complesso dei Ss. Apostoli, ed. Cosima Arcieri (Rome: Editalia, 1992), 19-21. Although whether the church was constructed by Constantine and/or rebuilt by Pelagius I is still debated; Liberal Gatti, La Basilica dei Santi XII Apostoli, 30 states that there are five columns in the basement which are dated earlier than the sixth century.

50 Valenti, "Le origini," 22. Martirion in the original Italian text.

51 Bonaventura, Compendio historico, 35. See also note 36. 
There is no information on the early representations of Saint Eugenia in the Church of the Apostles. There are only fifteenth-century reminiscences, although it seems that the saint was highly venerated -as indicated by the case of Cardinal Bessarione. Bessarione was named titular cardinal of the Church of the Apostles by Pope Eugenius IV in 1439. His palace, next to the church, was connected directly to the Chapel of Saint Eugenia in the Saint Apostles. ${ }^{52}$ This indicates that, in the fifteenth century, there was a separate sacred place dedicated to Saint Eugenia, which included the marble coffin with her and her mother's relics, making the eighteenth-century transfer impossible. This also implies that the chapel was dedicated to Saint Eugenia earlier than the fifteenth century when Bessarione decided to transform it into his burial place. In 1464-1465, he contracted Antoniazzo Romano to agree upon the iconography to be painted on the walls which he also included in his testament. ${ }^{53}$ These representations did not survive entirely, but the contract and Bessarione's testament did. They offer a glimpse on how the burial chapel might have looked like: Christ on throne surrounded by nine choirs of angels, with the Virgin, Saint John the Baptist, Saint Eugenia, and Bessarione:

Sul grande arcone che guarda l'altare: al centro (vi sia) il Cristo in trono con ai lati la santissima Vergine, l'Angelo (san Michele), san Giovanni Battista e Santa Eugenia. Ai piedi di Cristo, in ginocchio, la mia stessa imagine, e, al disotto di essa, il mio stemma. ${ }^{54}$

The tentative reconstruction of the chapel done by Carol M. Richardson (Fig. 5) ${ }^{55}$ shows that Saint Eugenia was placed closely to the Virgin Mary in the iconographic programme Then, around the

\footnotetext{
52 Lorenzo Finocchi Ghersi, "Bessarione e la basilica romana dei Santi XII Apostoli,” in Bessarione e l'Umanesimo, ed. Gianfranco Ficcadori (Naples: Vivarium, 1994), 129. See also Fabrizio Lollini, "Bessarione e le arti figurative," in Bessarione e l'Umanesimo, ed. Gianfranco Ficcadori (Naples: Vivarium, 1994), 149-170.

${ }^{53}$ Finocchi Ghersi, "Bessarione e la basilica romana," 130.

${ }^{54}$ Luigi Bandini, De vita et rebus gestis Bessarionis cardinalis Nicaeni, Appendix in Migne, Patrologia Graeca, 161. LXXIIIss. reproduced in Ippolito Mazzucco, "Scoperto e restauro nella Chiesa dei Santi XII Apostoli il ciclo pittorico di Santa Eugenia," Alma Roma. Bolletino d'informazioni 33 (1992): 4.

55 Carol M. Richardson, Reclaiming Rome: Cardinal in the Fifteenth Century (Leiden: Brill, 2009), 222-224.
} 
fifteenth-sixteenth century, Claudia and Eugenia (Fig. 6 and Fig. 7) started to be depicted on a lower register, next to Antoniazzo's Virgin Mary as a reflection of the growth of her cult as women martyrs were always connected to her (Fig. 8 see also Fig. 9 and 10). ${ }^{56}$ This pattern of Eugenia standing next to the Virgin is a later development and is also found in other regions of Italy as it will be shown.

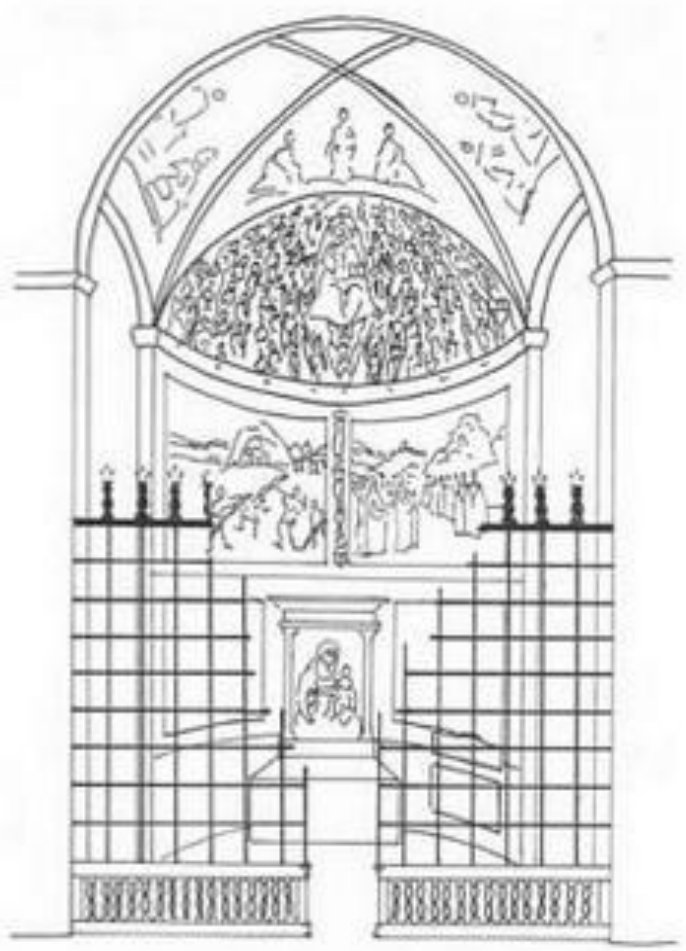

Fig. 5. Reconstruction of the Chapel of Saint Eugenia by Carol M. Richardson, Reclaiming Rome: Cardinals in the Fifteenth-Century (Leiden: Brill, 2009), 223.

\footnotetext{
56 Ippolito Mazzucco, "Scoperto e restauro," 5. Busiri-Vici, "Un ritrovamento eccezionale," 81: "Ai lati dell' edicola s'intravedono, poichè ancora non bene scoperte, due figure che appaiono dipinte in altra tecnica, e proporzioni di quelle di Antoniazzo.Probabilmente dovettero rappresentare le due Sante Claudia ed Eugenia."
} 
It must also be noted that Bessarione rededicated the Chapel of Saint Eugenia not only to her but also to Saint John the Baptist and the Archangel Michael who are mentioned in his testament as patrons of his burial chapel. ${ }^{57}$ The re-dedication and the inclusion of Saint Eugenia among the titular saints contributed, partially, to her survival in the seventeenth century (as Mavasia Bonaventura suggests ${ }^{58}$ ) and, even later, according to eighteenth-century inscriptions. ${ }^{59}$

Until this point, two aspects should be mentioned with regard to Saint Eugenia's cult in Rome. The first refers to the importance of the papal influence on the transfer from outside to inside Rome. The second relates to the constancy of Eugenia's representation as a martyr close to the side of Mary, particularly, inside Rome.

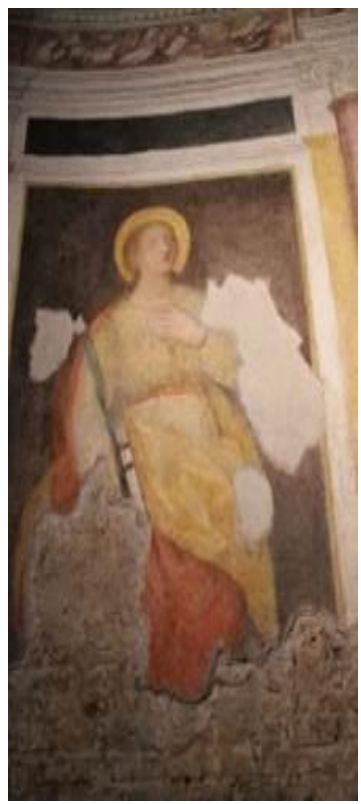

Fig. 6. Saint Eugenia, seventeenth-century (?). Church of the Apostles, Rome (photo: the author)

\footnotetext{
${ }^{57}$ Finocchi Ghersi, "Bessarione e la basilica romana," 130. Giuseppe Peroni was inspired by Duquesnoy's statue of Susana. The statue of Saint Claudia was done by Domenico Guidi with the help of Bernini.

58 Malvasia, Compendio bistorico, 36-39.

${ }_{59}$ Mazzucco, Iscrizioni della Basilica, 49.
} 


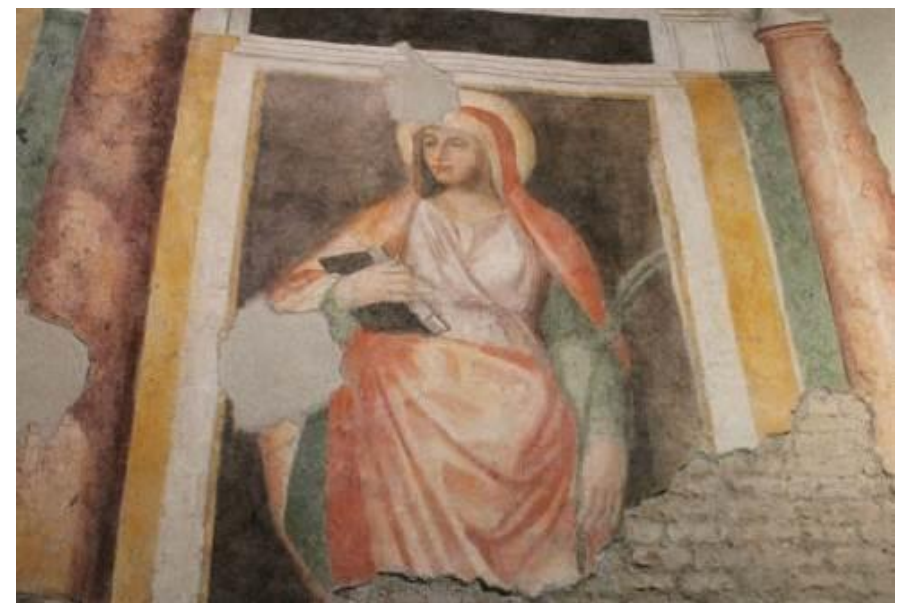

Fig. 7. Saint Claudia, seventeenth-century (?). Church of the Apostles, Rome (photo: the author)

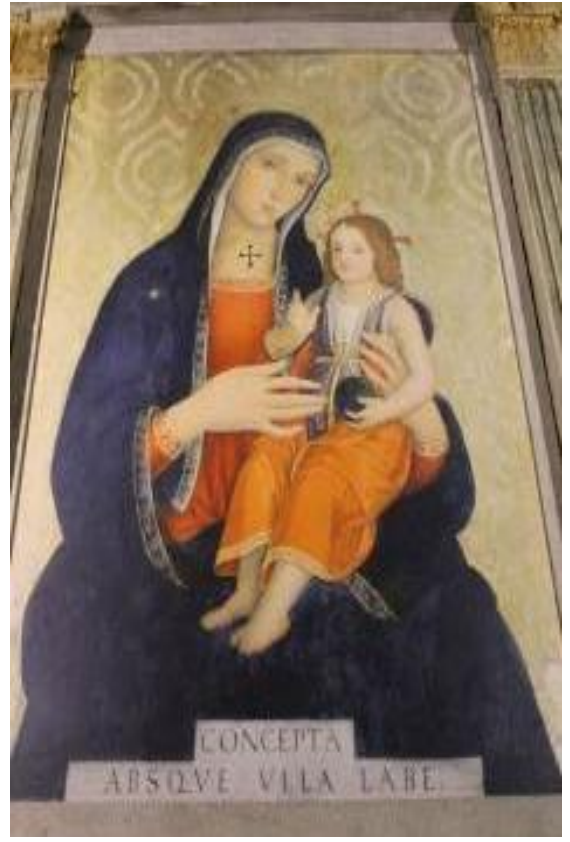

Fig. 8. Madonna of Cardinal Bessarion, c. 1467. Antoniazzo Romano, Church of the Apostles, Rome (photo: the author) 


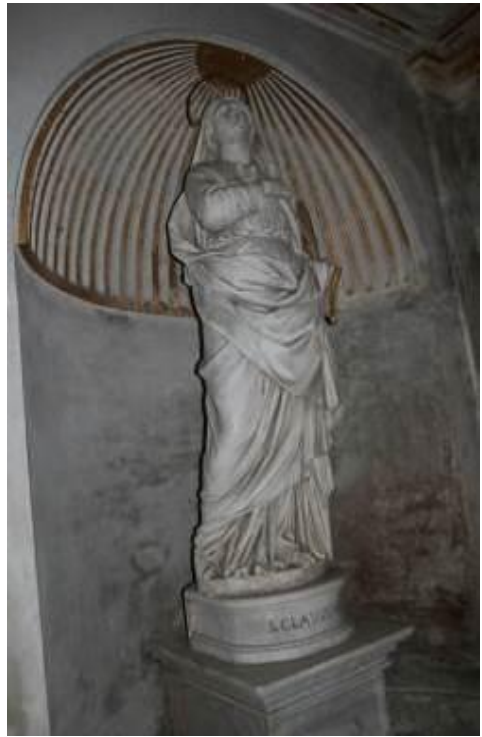

Fig. 9: Saint Claudia, seventeenth-century.

Domenico Guidi, Church of the Apostles, Rome (photo: the author)

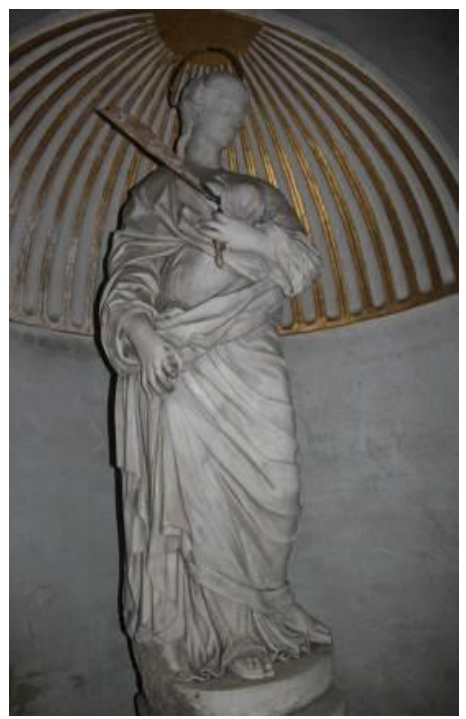

Fig. 10. Saint Eugenia, seventeenth-century, Francesco Peroni. Church of the Apostles, Rome (photo: the author) 


\section{Eugenia outside Rome: other phases}

The pattern of Eugenia next to the Virgin is not only specific for Rome. The Church of Bagnoro was dedicated to Saint Eugenia as early as the eighth century ${ }^{60}$ or perhaps much earlier in the fourth-fifth centuries $^{61}$ (possibly under influences from Ravenna ${ }^{62}$ ). Nothing has survived from the early church. In the fifteenth century, it underwent a redecoration and the only surviving interior fresco is the one depicting the Virgin with the Child (Fig. 11) represented similarly to the relief (Fig. 12) above the portal. ${ }^{63}$ This representation is similar to other depictions of Eugenia: with a martyr's palm and a book in her hands, frontally facing the viewer, she is positioned on the right side of the Virgin, while another martyr, Lawrence, is placed on the Virgin's left side. ${ }^{64}$ Considering that Eugenia was the titular saint of the church, there could have been a similar representation inside the Church of Bagnoro.

Similarly, in a fifteenth-century painting by Matteo di Giovanni (Fig. 14), Eugenia is placed next to Mary, although she has different iconographic characteristics. Formerly placed in the Church of Saint Eugenia from Siena, Eugenia is positioned on the left side of the Virgin, along with Saint John the Evangelist and two angels. The church, mentioned in twelfth-century documents, was later reconstructed. ${ }^{65}$ Scholarship has first identified the saint as Saint Eugenia and later as Saint Marina of Antioch/Margaret of Antioch. ${ }^{66}$ The exact identity of the saint is of particular importance here; rather, the importance lies on the way a certain figure with a certain identity

${ }^{60}$ Carla Corsi Miraglia, "Le Pieve di Sant'Eugenia al Bagnoro," Bolletino d'informazione 35 (1982): 16-17.

61 Angelo Tafi, La millenaria Pieve di S. Eugenia al Bagnoro (Arezzo: Calosci-Cortona, 1991), 31.

62 Fabio Gabbrielli, Romanico aretino. L'architettura protoromanica e romanica religiosa nella Diocesi medioevale di Arezzo (Florence: Salimbeni, 1990), 47.

63 Miraglia, "Le Pieve di Sant'Eugenia," 19. Gabbrielli, Romanico aretino, 73.

${ }^{64}$ Gabbrielli, Romanico aretino, 74.

65 Alfredo Liberati, "Chiese, monasteri, oratori e spedali Senesi," Bullettino Senese di storia patria (1956): 263-264. Sources suggest the existence of a monastery dedicated to Saint Eugenia in Lodovico Zdakauer, Il Costituto di Siena dal 1262, c. 337 (Siena, 1887) reproduced in Liberati, "Chiese, monasteri," 264, note 4.

${ }^{66}$ Erica Susanna Trimpi, Matteo di Giovanni: Documents and a Critical Catalogue of His Panel Paintings (Ann Arbor: The University of Michigan, PhD dissertation, 1987), 217-219. 
functioned for a religious community.In our case, a figure of a female saint was identified as Saint Eugenia, placed in a church of Saint Eugenia, and venerated as Saint Eugenia, not as Saint Marina of Antioch.

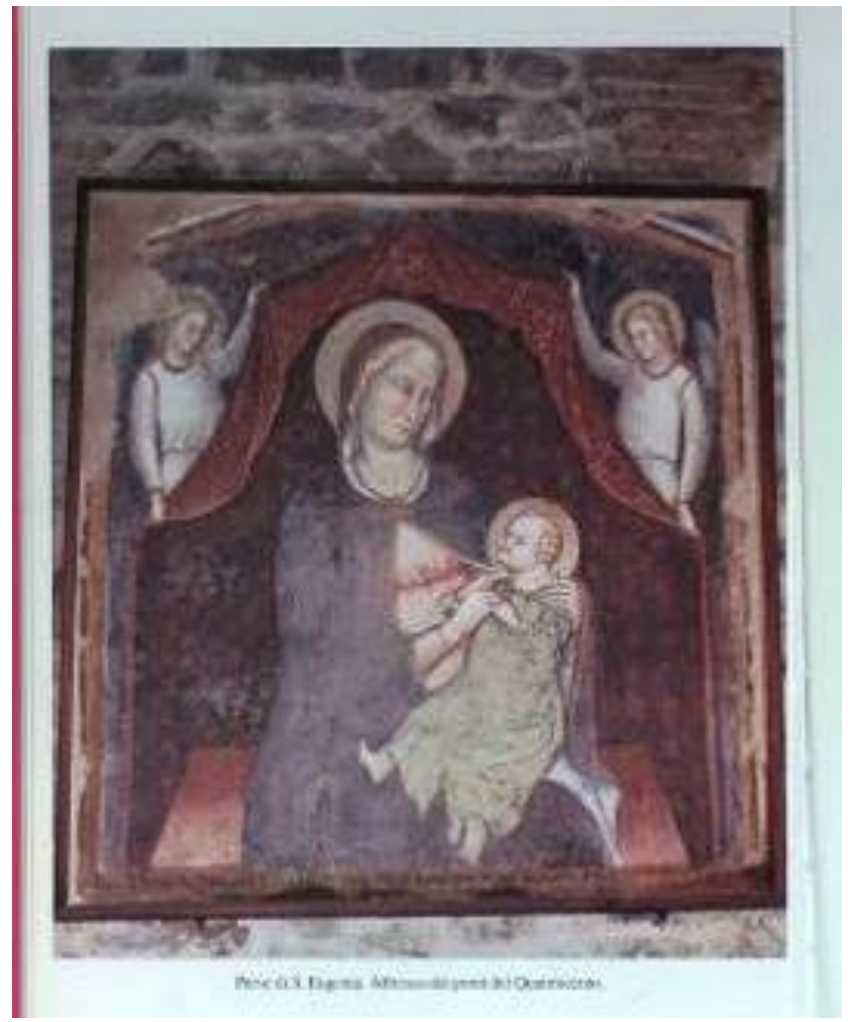

Fig. 12. The Virgin Mary, Church of Saint Eugenia, Bagnoro, Italy [(reproduced in Angelo Tafi, La millenaria Pieve di S. Eugenia al Bagnoro (Arezzo: Calosci-Cortona, 1991)]. 


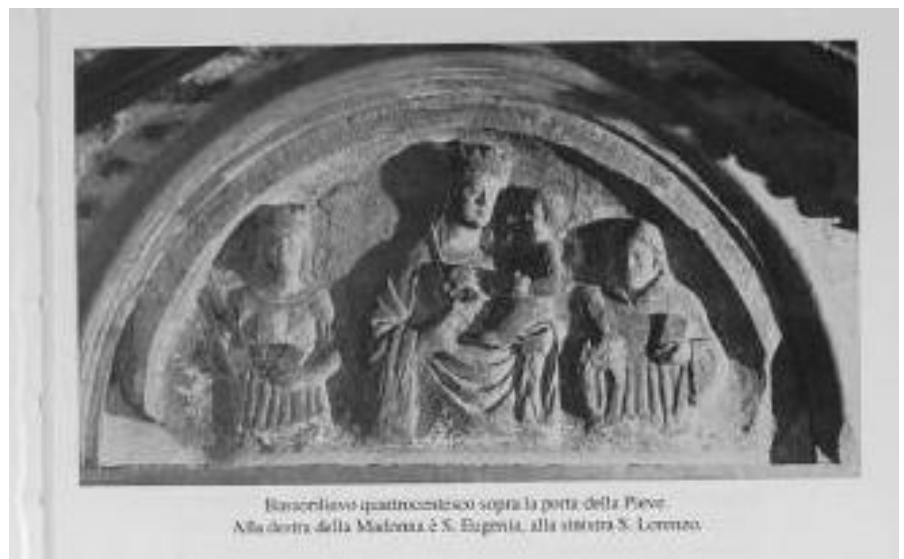

Fig. 13: The Virgin Mary with Saint Eugenia (right) and Saint Lawrence (left), Bagnoro, Italy [reproduced in Angelo Tafi, La millenaria Pieve di S. Eugenia al Bagnoro (Arezzo: Calosci-Cortona, 1991)].

In another fifteenth-century representation from Lombardia, Eugenia is in the company of two other virgin martyrs: Saint Catherine of Alexandria and Saint Agnes. The iconographic attributes of Eugenia are similar to her other representations from Italy: she is holding a martyr's palm and a sword and is clothed in a rather simple dress. Not only this representation, but all of the ones dating from the fifteenthcentury suggest a certain type of continuity with the earlier ones:, namely, Eugenia is represented as a female martyr both inside and outside of Rome. The textual sources related to her, poems, inscriptions, antiphons, all emphasize (besides her martyrdom) her chastity and virginity, through which she is connected to the ultimate model, Virgin Mary.

Therefore all these examples indicate Eugenia's closeness to Mary. This pattern of a virgin (martyr) next to the Virgin occurs in a time frame when the Marian cult and devotion started to emerge. Thus, Mary becomes a universal model also emulated by Eugenia and indicated by their iconographic closeness. Nevertheless, Eugenia is not only close to the Virgin. The above fifteenth-century examples indicate that Eugenia joins different groups of virgins or is paired with her mother, Claudia. This setting among women, again, emphasizes her femininity despite the importance of cross-dressing in her vita. 
To conclude, in both phases, inside and outside Rome, Eugenia is depicted as a martyr with certain differences. The transfer of her relics also meant the transfer of her iconography from one space, the Via Latina, to the other, The Church of the Apostles. Although the initial iconography cannot be traced, fifth-seventh-century mosaics from Ravenna indicate a possibility with regard to her representation as a martyr. This iconographic pattern survived and developed as the fifteenth-century fresco commissioned by Bessarione suggests. Also in her later representations, Eugenia is positioned close to the Virgin or other female saints, a fact which rather underscores her womanhood and not the ambiguous figure of a cross-dressed saint.

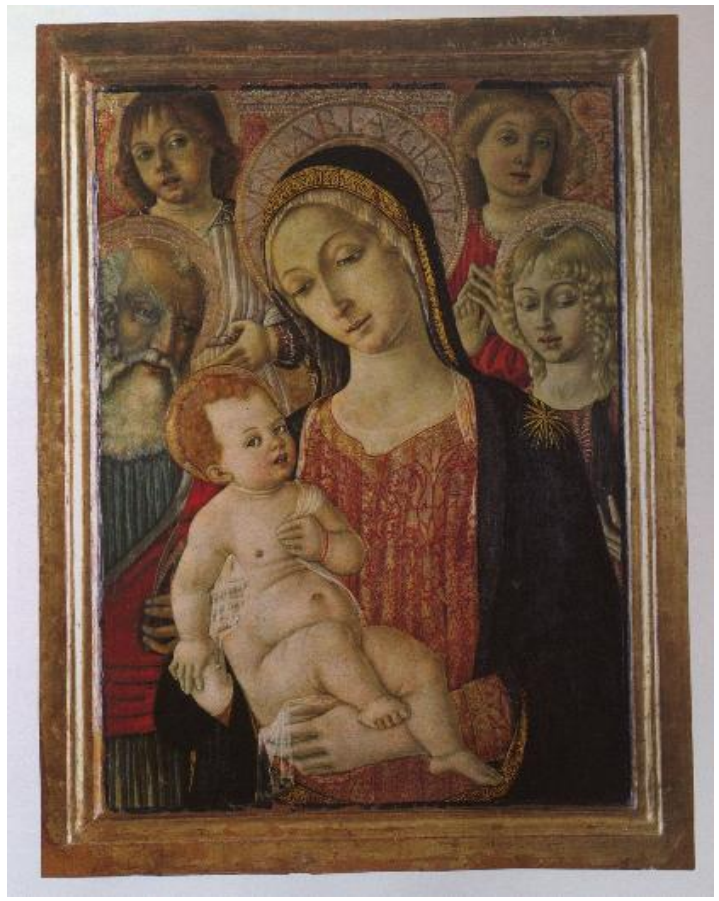

Fig. 14. The Virgin with Saint John the Evangelist and Saint Margaret of Antioch/Eugenia, fifteenth century, Matteo di Giovanni, Siena, Italy. [(reproduced in Alessandro Angelini, "Matteo di Giovanni: percorso esemplare di un quattrocentista senese" in Cronaca di una strage dipinta, ed. Cecilia Alessi, Alessandro Bagnoli (Siena: Ali Edizioni, 2006, 51)] 


\section{Bibliography}

Primary sources

Auctore incerto, "Vita Sanctae Eugeniae, virginis ac martyris," in AASS, Sept. 3: 761-62.

Dubois, Jacques. Le Martyrologe d'Usuard. Texte et commentaire. Brussels: Société des Bollandistes, 1965.

Duchesne, Louis. Le Liber Pontificalis, texte, introduction et commentaire, vol. I, II. Paris: Ernest Thorin, 1886.

Kaftal, George. Iconography of the Saints in the Paintings of North East Italy. Florence: Tipografia "L"Impronta", 1952. . Iconography of the Saints in Tuscan Painting. Florence: Tipografia

"L"Impronta," 1952. . Saints in Italian Art, Iconography of the Saints in Central and South Italian Schools of Painting. Florence: Sansoni, 1975.

Malvasia, Bonaventura. Compendio historico della ven. Basilica di SS. Dodeci Apostoli di Roma, sua fondazione, origine, nobilita, sito, pretiosi tesori delle Sante Reliquie, che in quella si contengono. Rome: 1665.

Rossi, de Giovanni Battista. La Roma sotterranea Cristiana, vol. I. Rome: Cromo-Litografia Pontificia, 1864.

Stolfi, Casimiro. Leggende di alcuni santi e beati venerati in Santa Maria degli Angeli di Firenze. Bologna: Commissione per testi di lingua, 1968.

The Martyrologum Romanum. Rome: Typis Polyglottis Vaticani, 1930.

\section{Secondary sources}

Usener, Hermann. Legenden der heiligen Pelagia. Bonn: Adolph Marcus, 1879.

Delehaye, Hippolyte. The Legends of the Saints. Brussels, 1905, 1906, reprinted Dublin: Four Courts Press, 1998.

Anson, John. "The Female Transvestite in Early Monasticism: The Origin and the Development of a Motive." Viator 5 (1974): 1-32.

Patlagean, Évelyne. "L'histoire de la femme déguisée en moine et l'évolution de la sainteté feminine a Byzance." Studi Medievali 17, No. 3 (1976): 597-623.

Bullough, Vern L. "Transvestites in the Middle Ages." The American Journal of Sociology 79(6) (1974): 1381-1394. 
Bullough, Vern L.; Brundage, James. Handbook of Medieval Sexuality: $A$ Book of Essays. New York: Garland Publishing, 1996. . Cross-Dressing, Sex, and Gender. Philadelphia: University of Pennsylvania Press, 1993.

Schein, Sylvia. "The Female Men of God and Men Who Were Women.

Female Saints and Holy Land Pilgrimage During the Byzantine Period." Hagiographica 5 (1998): 1-36.

Harvey, Susan Ashbrook. "Women in Early Byzantine Hagiography: Reversing the Story." In That Gentle Strength: Historical Perspectives on Women in Christianity, ed. L. Coon, Katherine J. Haldane, and Elisabeth W. Sommer, 36-39. Charlottesville: University Press of Virginia, 1990.

Castelli, Elizabeth. "I Will Make Mary Male: Pieties of the Body and Gender Transformation of Christian Women in Late Antiquity." In Body Guards: the Cultural Politics of Gender Ambiguity, ed. Julia Epstein and Kristina Straub, 29-49. New York: Routledge, 1991.

Delcourt, Marie. "Le Complexe de Diane et l'hagiographie Chretienne." Revue de l'bistoire des religions 153 (1958): 1-33.

Davis, Stephen, J. "Crossed Texts, Crossed Sex: Intertextuality and Gender in Early Christian Legends of Holy Women Disguised as Men." Journal of Early Christian Studies 10, No. 1 (2002): 1-36.

Davis, Natalie Zemon. Society and Culture in Early Modern France. Stanford: Stanford University Press, 1975.

Lubinsky, Crystal. Removing Masculine Layers to Reveal a Holy Womanhood. The Female Transvestite Monks of Late Antique Eastern Christianity. Turnhout: Brepols, 2013.

Amore, Agostino. I martiri di Roma. Todi: Tau Editrice, 2013.

Baert, Barbara. "More Than an Image: Agnes of Rome: Virginity and Visual Memory." In More than Memory: the Discourse of Martyrdom and the Construction of Christian Identity in the History of Christianity, ed. Johan Leemans, 139-168. Leuven: Peeters Publishers, 2005.

Bartolini, Domenico. Cimitero d'Aproniano ditto anche di Santa Eugenia su la via Latina. Rome: Tipografia delle delle Arti, 1840.

Busiri-Vici, Clemente. "Un ritrovamento eccezionale relative all'antica basilica dei Ss. Apostoli." Roma, Fede e arte, 8 (1960): 70-83.

Corsi, Miraglia, Carla. "Le Pieve di Sant'Eugenia al Bagnoro.” Bolletino d'informazione 35 (1982): 16-36. 
Delehaye, Hippolyte. Étude sur le légendier romain. Les saints de novembre et de décembre, vol. I. Brussels: Société des Bollandistes, 1936. . Les Origines du culte des martyrs. Brussels: Société des Bollandistes, 1933.

Duby, George. Power and Beauty: Images of Women in Art. London: Tauris Parke Books, 1992.

Dufourcq, Albert. Étude sur le Gesta Martyrum Romains. Paris: Albert Fontemoing éditeur, 1900.

Fabbri, Maria Pia. I mosaici di Ravenna. Forli: Carta Canta Editore, 2010.

Fattorini, Gabriele. "Madonna col bambino, i santi Giovanni Evangelista (?), Margherita d'Antiochia e due angeli." In Matteo di Giovanni. Cronaca di una strage dipinta, ed. Cecilia Alessi, Alessandro Bagnoli, 50-53. Siena: Ali Edizioni, 2006.

Gabbrielli, Fabio. Romanico aretino. L'architettura protoromanica e romanica religiosa nella Diocesi medioevale di Arezzo. Florence: Salimbeni, 1990.

Gatti, Isidoro Liberal. La Basilica dei Santi XII Apostoli. Rome: L' Apostoleion, 1988.

Ghersi, Lorenzo Finocchi. "Bessarione e la basilica romana dei Santi XII Apostoli." In Bessarione e l'Umanesimo, ed. Gianfranco Ficcadori, 129-136. Naples: Vivarium, 1994.

Gordini, Gian Domenico. "Filippo, Eugenia; Abdon, Sergio, Claudia Proto e Giacinto." Bibliotheca Sanctorum vol. I, ed. Istituto Giovanni XXIII nella Pontificia Università lateranense, 181-183. Rome: Cità Nuova Editrice, 1964.

Josi, Enrico. "Cimitero Cristiano sulla Via Latina." Rivista di archeologia cristiana 16 (1939): 19-50.

Liberati, Alfredo. "Chiese, monasteri, oratori e spedali Senesi." Bullettino Senese di storia patria (1956): 224-264.

Lollini, Fabrizio. "Bessarione e le arti figurative." In Bessarione e l'Umanesimo, ed. Gianfranco Ficcadori, 149-170. Naples: Vivarium, 1994.

Mazzucco, Ippolito. "Scoperto e restauro nella Chiesa dei Santi XII Apostoli il ciclo pittorico di Santa Eugenia." In Alma Roma. Bolletino d'informazioni, ed. Giuseppe Scarfone, 3-11. Rome, N.1-2, Year 33, 1992, January-April 1992.

. Iscrizioni della Basilica e convento dei Santi Dodici Apostoli in Roma. Rome: L'Apostoleion, 1987. 
Morini, Enrico. "Santità monastica femminile in abiti maschili nell'Oriente cristiano." In Giustina e le altre. Sante e culti femminili in Italia settentrionale dalla prima età cristiana al secolo XII, ed. Andrea Tilatti, Francesco G.B. Trolese, 271-300. Padova: Viella, 2009.

Richardson, Carol M. Reclaiming Rome: Cardinal in the Fifteenth Century. Leiden: Brill, 2009.

Schein, Sylvia. "The Female Men of God and Men Who Were Women.

Female Saints and Holy Land Pilgrimage During the Byzantine Period." Hagiographica 5 (1998): 1-36.

Schulenburg, Jane Tibbetts. Forgetful of Their Sex: Female Sanctity and

Society, c. 500-1100. Chicago and London: University of Chicago Press, 1998.

Tafi, Angelo. La millenaria Pieve di S. Eugenia al Bagnoro. Arezzo: CalosciCortona, 1991.

Terry, Ann and Henry Maguire. Dynamic Splendor. The $W$ all Mosaics in the Cathedral of Eufrasius at Poreč, vol. I. Philadelphia: Pennsylvania State University Press, 2007.

Toursel, Zéphyrin. Histoire de Sainte Eugénie, vierge romaine, et de sa famille. Lille: Jesuit Library of Lille, 1860.

Trimpi, Erica Susanna. "Matteo di Giovanni: Documents and a Critical Catalogue of His Panel Paintings." Ann Arbor: University of Michigan, PhD dissertation, 1987.

Verzone, Paolo. "Il palazzo arcivescovile e l'olatorio di S. Andrea." In Corsi di cultura sull'arte ravennate e bizantina, ed. Giuseppe Bovini, 445454. Ravenna: Edizioni Dante, 1966.

Zdakauer, Lodovico. Il Costituto di Siena dal 1262, cc. 337, Siena, 1887. Reproduced in

Liberati, Alfredo. "Chiese, monasteri, oratori e spedali Senesi." Bullettino Senese di storia patria (1956): 224-264.

Znorovszky, Andrea-Bianka. "Between Mary and Christ: Depicting Cross-Dressed Saints in the Middle Ages (c. 1200-1600)." Budapest: Central European University, PhD dissertation, 2016. Zocca, Emma. La Basilica dei Ss. Apostoli in Roma. Rome: F. Canella, 1959.

Zucchetti, Valentini. Codice topografico della città di Roma, vol. II. Rome: Tipografia del Senato, 1942. 